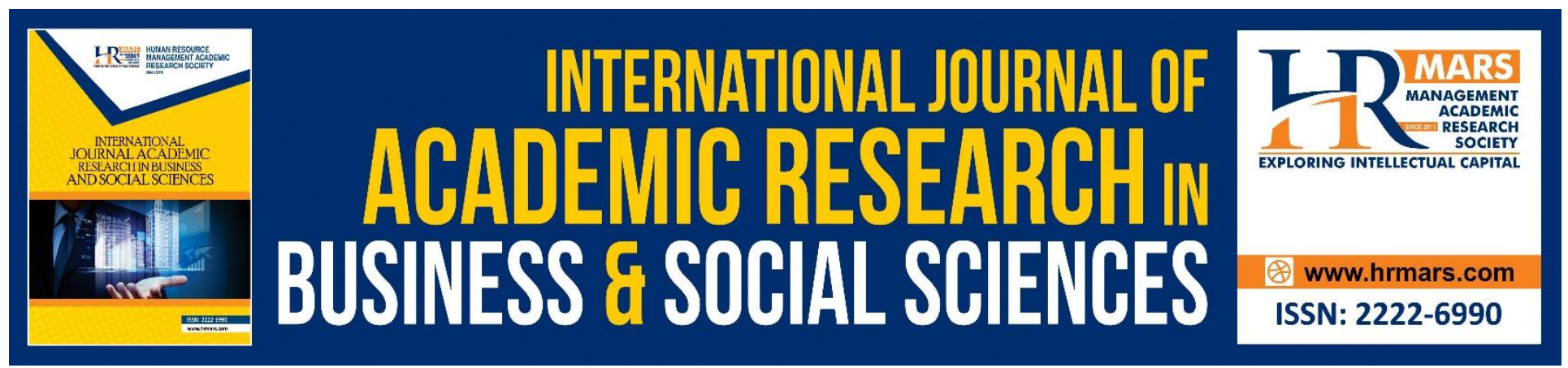

\title{
The Impact of Psychopathy on Counterproductive Work Behavior
}

Rub Nawaz, Muhammad Zia-ud-Din, Muhammad Tahir Nadeem, Mohy ud Din

To Link this Article: http://dx.doi.org/10.6007/IJARBSS/v8-i7/4336

DOI: $10.6007 /$ IJARBSS/v8-i7/4336

Received: 24 June 2018, Revised: 10 July 2018, Accepted: 29 July 2018

Published Online: 30 July 2018

In-Text Citation: (Nawaz, Zia-ud-Din, Nadeem, \& Din, 2018)

To Cite this Article: Nawaz, R., Zia-ud-Din, M., Nadeem, M. T., \& Din, M. ud. (2018). The Impact of Psychopathy on Counterproductive Work Behavior. International Journal of Academic Research in Business and Social Sciences, 8(7), 208-220.

\section{Copyright: (C) 2018 The Author(s)}

Published by Human Resource Management Academic Research Society (www.hrmars.com)

This article is published under the Creative Commons Attribution (CC BY 4.0) license. Anyone may reproduce, distribute, translate and create derivative works of this article (for both commercial and non-commercial purposes), subject to full attribution to the original publication and authors. The full terms of this license may be seen

at: http://creativecommons.org/licences/by/4.0/legalcode

Vol. 8, No. 7, July 2018, Pg. 208 - 220

http://hrmars.com/index.php/pages/detail/IJARBSS

JOURNAL HOMEPAGE

Full Terms \& Conditions of access and use can be found at http://hrmars.com/index.php/pages/detail/publication-ethics 


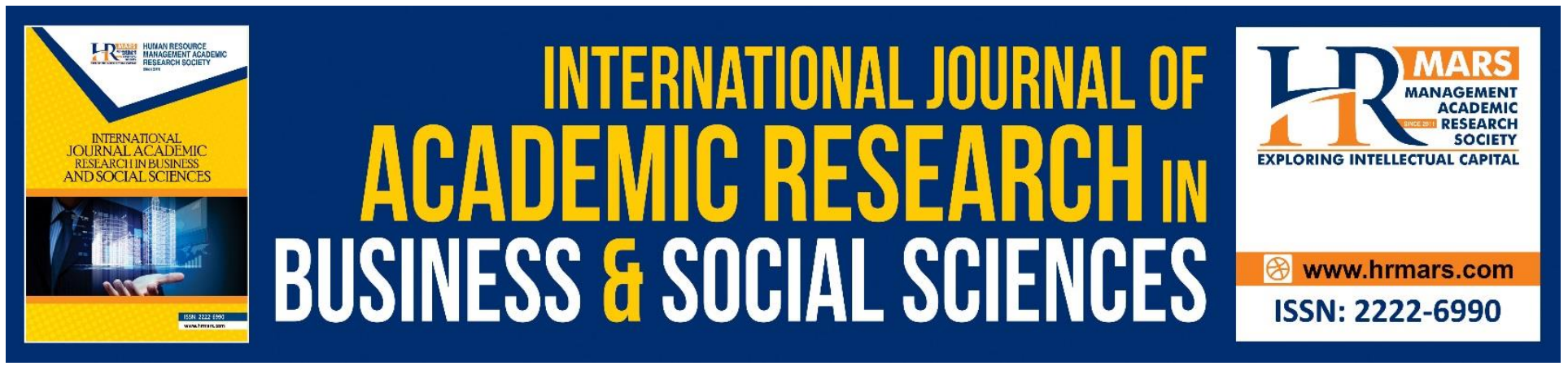

\title{
The Impact of Psychopathy on Counterproductive Work Behavior
}

\author{
Rub Nawaz \\ MPhil Scholar (Department Public Administration) \\ Government College University, Faisalabad Pakistan \\ Email: rub.nawaz10805@gmail.com \\ Muhammad Zia-UD-Din \\ Lecturer (Department Public Administration) \\ Government College University, Faisalabad Pakistan \\ Muhammad Tahir Nadeem \\ MPhil Scholar (Department Public Administration) \\ Government College University, Faisalabad Pakistan \\ Mohy ud Din \\ MPhil Scholar (Department Public Administration) \\ Government College University, Faisalabad Pakistan
}

\begin{abstract}
This study was primarily conducted to understand the impact of psychopathy on counterproductive work behavior. Data was collected from 130 personnel through convenience sampling technique, using adopted questionnaires consisting of measuring each variable on fivepoint liker scales. For data analysis statistical tools such as reliability, correlation and Regression were used. Results indicate psychopathy has significant relationship with counterproductive work behavior. The mediating role of workplace aggression between psychopathy and counterproductive work behavior was also supported by results. Therefore, organization should be used psychopathy as an important mental focus to reduce the negative emotions of the employees for managing the counterproductive work
\end{abstract}

Keywords: - Psychopathy, Employee Larceny, Workplace Aggression, Counterproductive Work Behavior. 
INTERNATIONAL JOURNAL OF ACADEMIC RESEARCH IN BUSINESS AND SOCIAL SCIENCES Vol. 8, No. 7, July 2018, E-ISSN: 2222-6990 @ 2018 HRMARS

\section{Background}

According to Suzy, Paul and Spector (2015) Counterproductive work behaviors are extremely costly for organization. Counterproductive work behaviors are those behaviors that are intentionally conducted by employees and harm an organization and its members (Harris \& Ogbonna, 2014). American statistics estimate that the cost of internet misusing is rising up to $\$ 85$ billion. It is estimated that every year total cost of internal theft is almost $\$ 50$ billion. It is also estimated that Counterproductive work behavior is responsible for business failures and yearly business sales (Dennis, \& Self-Terry, 2014).

There are three categories of job behavior form overall job performance: task, citizenship, and CWBs (Rui-Ting, Hsi-Sheng, Chia-Hua, \& Ching-Wen, 2017). A CWB including five facets. Abuse largely is including overlaps with ID one of these facets, whereas the other four are deviance, theft, sabotage and withdrawal mainly targeted at the organization. (Rui-Ting et al 2017).

According to an Empirical Study on CWB is characterized psychopathy as, "an arrangement of volitional acts that damage or expect to mischief associations and their partners e.g., customers, collaborators, clients, and administrators" (Jonas, Joeri, \& Filip, 2016).

Organizations are effective which have roused workers as they beat the unsatisfied workers of different organizations (Habib-ur-Rehman, Idrees, \& Ullah, 2017). Unsatisfied workers will probably take part in counterproductive work behavior i.e. taking long breaks, working slowly and breaking rules (Habib-ur-Rehman et al 2017). Management of organization must focus on limiting these behaviors in the workplace to increase the level of motivation of workers so overcome the issues arise due to the counter productive work behaviors of the workers (Misbah, \& Ambreen, 2012).

More specifically, the aim of this research study is to explore the effect of counterproductive work behavior of quality of administrative leadership and to investigate the moderating role of employee relationship.

\section{Problem Statement}

Researchers have been studying the impact of family rudeness on counterproductive work behavior but little mental focus has been paid to mechanisms which can act as stabilize and soften the Impact of negative outcomes (Mahmood, Hameed, \& Haider, 2017).. First of all, mediating role of workplace aggression and mediating Role of workplace aggression support has not been addressed in literature in this relation. Secondly studies generally conducted in developing countries but in under develop countries like Pakistan studies conducted are infrequent. In order to reduce such type of negative behavior some kind of support is required that is helpful for employees in time support may be the one who is least adversely affected by life changes.

\section{Research Questions}

Research questions are generated by keeping in view of following the theoretical framework

1. What is the effect of Psychopathy on Counterproductive work behavior?

2. What is the effect of Employee larceny on Counterproductive work behavior?

3. What is the effect of Psychopathy on Counterproductive work behavior under the mediation role of workplace aggression?

4. What is the effect of Employee larceny on Counterproductive work behavior under the mediation role of workplace aggression? 
INTERNATIONAL JOURNAL OF ACADEMIC RESEARCH IN BUSINESS AND SOCIAL SCIENCES Vol. 8, No. 7, July 2018, E-ISSN: 2222-6990 @ 2018 HRMARS

\section{Study of the Objective}

By taking the view objectives are achieved following the above research questions

1. To examine the effect of Psychopathy on Counterproductive work behavior.

2. To examine the effect of Employee larceny on Counterproductive work behavior.

3. To investigate the effect of Psychopathy on counterproductive work behavior under the mediation role of workplace aggression.

4. To examine the effect of Employee larceny on counterproductive work behavior under the mediation role of workplace aggression.

\section{Significance of the Study}

This study will help the public-sector organizations that why and how their employees feel disliked and ultimately resulted in counter work behaviors. Not only this, but also the whole mechanism that how employee resulted in negative work behaviors. Employees faced by different behaviors, for instance if they felt is liked behaviors from other employees, more chances for the weakened their affective commitment, job performance and intentions to quit and work engagement (Khan, 2016). However, there are studies who mentioned that workplace shunning has negative impact on employee's outcomes and there is still question about that how an individual can handle with their feelings when he/she has been disliked by others and yet they have still connected with those colleagues is yet unexplored. This study will help the public-sector organizations to identify the complex relationship of workplace dislike and counterproductive work behaviors and it will help timely to classify the behaviors of disliked employees in an organization and resolve the problem effectively and efficiently to prevent from big losses (ㅁaza, Jawaid, \& Hassan, 2015). Psychopathy is the basic personality trait in psychology domain and it is characterized by anxiety, moodiness, fear, envy and frustration. The study suggested that there is positive relationship of psychopathy, with distrust. Whenever there are employee's larceny working in an organization they are more lying to establish negative behaviors in organizations and lead to poor performance, i.e. firm performance (Mahmood, 2005).

\section{Purpose of the Study}

Purpose of the study is to create the impact of psychopathy on work counterproductive behavior. This study has also great significance for textile sectors. It provides guidance to executives to expand the level of occupation fulfillment and organizational trust of employees by counteracting inconsiderate conduct at work environment. In doing as such, it tested Organization's dedication of amazing watch over its partners. The benefit of understanding useful exchanges in Organization is likewise evaluated by investigated appraisals of any social and impactful undercurrents of psychopathy the organization.

\section{Literature Review}

\section{Counterproductive Work Behavior}

Counterproductive work behavior is defined as such type of behavior that disregard the rules norms of organization and its purpose is to harm the organization or people working their Counterproductive work behavior can take different forms of violence, deviance, revenge, cyber loafing (Habib-ur-Rehman et al 2017). In order to get free of this type of behavior, it is very difficult for us to point out its possible antecedents( Jawaid et al 2017). Counterproductive work behavior is not only a single type of behavior but also aggregated set of behaviors. By comparing it with single 
INTERNATIONAL JOURNAL OF ACADEMIC RESEARCH IN BUSINESS AND SOCIAL SCIENCES Vol. 8, No. 7, July 2018, E-ISSN: 2222-6990 @ 2018 HRMARS

type of behavior we come to know that counterproductive work behaviors are more constant and valid regarding time/personality and situational variables (Lobnikar \& Pagon, 2014). Consistency in personality variables was very high than situational variable as personality limits a person's behavior while situation encourages behavior of a person so it is more valuable to study it (Kari, Stacey, \& Paul, 2014). Some empirical research showed that employees counterproductive work behavior can be increased by workplace ostracism and in this way individual differences can be recognized (Caroline, \& Vincent, 2014). Literature has shown that workplace shunning may result in depression and maladaptive (such type of behavior not provides adequate adjustment for suitable environment or situation. Shunning type of behavior should be avoided in the organizations as research has shown that workplace aggression and counterproductive work behavior are positively related. According to Chockalingam, Satish and Claudio (1998) counterproductive work behavior contains two types of behaviors as one occurs within organization (stealing any type of material) or among employees/individual (using loose talks and starts abusing one another).

\section{Workplace Aggression}

Employee aggression is defined as acts of employees to harm others with whom they work. The word aggression means behavior that harms others at workplace either in physical or nonphysical form (yelling or pushing) and has been shown to be one of the most com and important form of interpersonal abuse (Yong, Xiaozhi \& Zhaozhong, 2010). In past research antecedent of aggression target individual characteristics and job experiences (Christopher, Whelpley, \& Michael, 2016). However, suggest that situational factors such as leadership, organizational weather play vital role in employee's response to aggression at workplace and other types of mistreatment (Suzy, Paul, \& Spector, 2015). Individual differences play a significant role in aggression and are responsible for creating aggression at workplace (Amjad, \& Al-Nasser, 2015). Literature on social learning theory, on aggression, revealed that environment plays an energetic role in determining whether employees display aggressive behavior or not. According to Mingzheng, Xiaoling, Delin, and Ci (2016) stealing, abuse co-workers, not providing possible resources in time, spreading reports, damaging office's tackle/material, arriving late are all those negative outcomes that are responsible for making employees aggressive at work place (Yan, \& Long, 2017),". For example, found that employees who come to know that they have to leave their job and throw out from workplace, they will enlist themselves in harmful behaviors i.e. they become impolite at workplace and bullying their co-workers that will affect their relation with them in future. Researchers have found that $25 \%$ changes occur in aggression are due to personality (Rui-Ting et al, 2017).

\section{Psychopathy}

According to work-home resource model behavioral work outcome (counter productive work behavior) is influenced by background demand (family incivility) in home domain. Literature reveals that whenever employees feel unhappy at work they are involved in deviant work place behavior (Ullah, 2016). Psychopathy plays a vital role in bringing negative behavior at work. For example, child disease is the reason due to which employee becomes unable to perform well as the stress that helshe faces at home spills over at workplace and affects his/her performance. According to Satish, Jacob and Xiaonan (2005) experiences in family may spillover to affect mood and behavior at workplace and negatively affect performance. Counterproductive work behavior is the effective different work behavior that plays a significant role in organizational success and survival. Counterproductive work behavior is considered as a behavior that is totally different from behavior 
INTERNATIONAL JOURNAL OF ACADEMIC RESEARCH IN BUSINESS AND SOCIAL SCIENCES Vol. 8, No. 7, July 2018, E-ISSN: 2222-6990 @ 2018 HRMARS

of other person in the organization (Manuela, Anja, Bruno, 2017). Various factors are responsible for creating counterproductive work behavior such as individual differences among employees, such as personality trait, working abilities, job experiences, and worse working environment \condition, strict supervision, interpersonal conflict. However, psychopathy might be vaguer as compared to workplace incivility, and it can easily be ignored (Alexander, \& Nick, 2016).

\section{Employee Larceny}

Employee Larceny is excessively characterized as In-part performance. EL shows the mechanized highlights of a worker's job (Mahmood, Hameed, \& Haider,2006). It says unmistakable usage of the errands vital in work. Undertaking practices totally back close difference in crude supplies into definite products or administrations (Joseph, Yoerger, \& Lehmann-Willenbrock, 2015). Dennis depicted TP "helping and section of the workflow that converts resources, information and efforts of energy into productions in the form of goods and facilities to the outdoor population." Task actions regularly shift from employment to work yet foundation activities are proceeded with normal to visit occupations (Wenzhi, Yen-Chun, XiaoChen, \& Shu-Jou 2017).

\section{Hypothesis}

Hypothesis develop following above-mentioned study of the objective.

$\mathrm{H} 1$ : There is a significant between psychopathy and counterproductive work behavior.

$\mathrm{H} 2$ : There is a significant relationship between employee larceny and counterproductive work behavior.

H3: There is a significant relationship between psychopathy and counterproductive work behavior under the mediation role of workplace aggression.

$\mathrm{H} 4$ : There is a significant relationship between employee larceny and counterproductive work behavior under the mediation role of workplace aggression. 


\section{Theoretical framework}

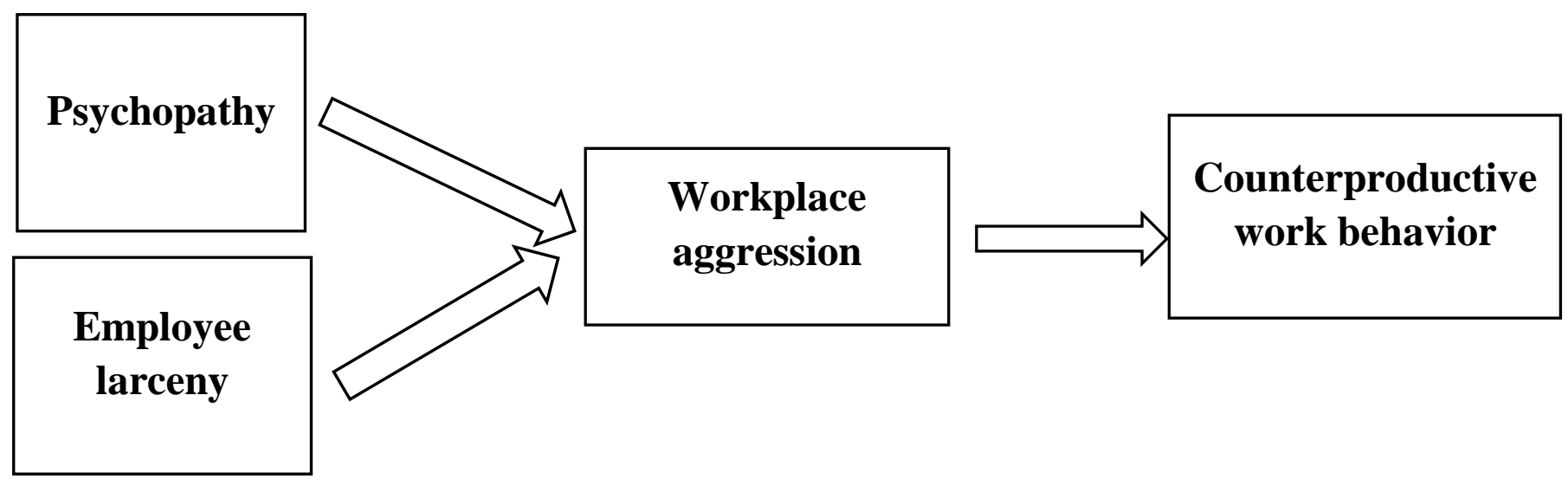

\section{Methodology}

For better understanding the impact of counterproductive work behavior (CWB) on Workplace aggression (WPA) observed study is done. The investigation for the examination are managers working in vital positions in the textile sector of Faisalabad. Add up to 130 surveys are appropriated among the supervisors of the material associations and 120 questionnaires are endeavored with answer rate of $92.6 \%$. For checking the relationship of factors, connection examination is utilized. Relapse investigation is additionally used to check reason and impact connection among factors. For testing hypothesis SPSS 23.0 software is utilized.

\section{Scale and Questionnaire}

Using 12 items to measure the counterproductive work behavior and the scale is adopted). 7 items used to measure employees' psychopathy (PP) and use a scale developed. Moreover, six items used to measure the Employee larceny (EL) and scale is adopted. We measured workplace aggression by using 7 items and scale used, developed. 
INTERNATIONAL JOURNAL OF ACADEMIC RESEARCH IN BUSINESS AND SOCIAL SCIENCES

Vol. 8, No. 7, July 2018, E-ISSN: 2222-6990 @ 2018 HRMARS

\section{Descrirptive Statistics}
$\mathrm{F}$
$\%$

\begin{tabular}{lll}
\hline $20-25$ & 12 & 10.0 \\
$26-30$ & 37 & 30.8 \\
$31-35$ & 34 & 20.3 \\
$36-40$ & 25 & 28.8 \\
$41-45$ & 11 & 9.2 \\
$46-50$ & 1 & .8 \\
Intermediate & 4 & 3.3 \\
Bachelor & 28 & 23.3 \\
Master & 62 & 51.7 \\
MS/MPhil & 25 & 20.8 \\
PhD & 1 & 8 \\
& & \\
HR & $\mathrm{F}$ & $\%$ \\
Production & 50 & 41.7 \\
Administration & 15 & 12.5 \\
Others & 32 & 26.7 \\
Total & 23 & 19.2 \\
\hline
\end{tabular}

Qualification, there are 62 participants holding the degree of Master with $51.7 \%$ and 28 participants t holding the degree of graduation with $23.3 \%$. Further 25, 4, 1 participants holding the degree MS/MPhil, Intermediate and PhD.

Age, there were 12 participants fell into the group of $20-25$ with $10 \%$ and 37 participants that into group of 26-35 with $30.8 \%$. Further 34participants into the category of 31-35 with $20.3 \%$ and 25 participants with $28.8 \%$ into the category of $36-40$. Further, 11 participants with $9.2 \%$ into the category of $41-45$ and I participant with the $.8 \%$ into the category of $46-50$

Department, there were 50 participants that into the group of HR with $41.7 \%$ and 15 participants that into group of Production with 12.5\%. Further 32, 23 participants fall into the group of Administration and Others respectively with $26.7 \%$ and $19.2 \%$. 
INTERNATIONAL JOURNAL OF ACADEMIC RESEARCH IN BUSINESS AND SOCIAL SCIENCES Vol. 8, No. 7, July 2018, E-ISSN: 2222-6990 (C) 2018 HRMARS

\section{Reliability and Correlation}

Table depicts that the relationship is positive of counterproductive work behavior with Employee Larceny with a value of .965, which is significant at $1 \%$. It is also shown that the relation is positively associated of Workplace aggression with Psychopathy with a value of .567. Similarly, the relationship is positively associated of CWB with Psychopathy with a value of .410. Further the relation is positively associated of Employee Larceny with Workplace aggression with a value of .494. Similarly, the relation is also positively associated of CWB with employee larceny with a value of .501. Table also shows that the relation is positively associated Workplace aggression with CWB with a

\begin{tabular}{llllll}
\hline & A & Psychopathy & Employee Larceny & Workplace_agression & CWB \\
\hline $\begin{array}{l}\text { Psychopathy } \\
\begin{array}{l}\text { Employee } \\
\text { Larceny }\end{array}\end{array}$ & .785 & 1 & $.965^{* *}$ & 1 & \\
$\begin{array}{l}\text { Workplace } \\
\text { aggression }\end{array}$ & .832 & $.567^{* *}$ & $.494^{* *}$ & 1 & \\
$\begin{array}{l}\text { CWB } \\
\text { 794 }\end{array}$ & $.410^{* *}$ & $.501^{* *}$ & $.511^{* *}$ & 1 \\
\end{tabular}

** Correlation is significant at the 0.01 level (2-tailed).

value of .51

\section{Regression analysis}

Model Summaryc

\begin{tabular}{|c|c|c|c|c|c|}
\hline Model & $\mathrm{R}$ & R Square & $\begin{array}{c}\text { Adjusted R } \\
\text { Square }\end{array}$ & $\begin{array}{l}\text { Std. Error of } \\
\text { the Estimate }\end{array}$ & Durbin-Watson \\
\hline 1 & $.915^{a}$ & .838 & .835 & .17183 & \\
\hline 2 & $.915^{b}$ & .838 & .833 & .17257 & 1.946 \\
\hline
\end{tabular}

a. Predictors: (Constant), Employe_Larceny, Psychopathy

b. Predictors: (Constant), Employee_Larceny, Psychopathy, Workplace_agression

c. Dependent Variable: Counterproductive_workbehavior

ANOVAa

\begin{tabular}{llrrrrr}
\hline Model & & Sum of Squares & Df & Mean Square & $\mathrm{F}$ & \multicolumn{1}{c}{ Sig. } \\
\hline \multirow{2}{*}{1} & Regression & 17.820 & 2 & 8.910 & 301.774 & $.000^{\mathrm{b}}$ \\
& Residual & 3.455 & 117 & .030 & & \\
& Total & 21.275 & 119 & & & \\
& Regression & 17.820 & 3 & 5.940 & 199.466 & $.000^{\mathrm{c}}$ \\
2 & Residual & 3.455 & 116 & .030 & & \\
& Total & 21.275 & 119 & & & \\
\hline
\end{tabular}

a. Dependent Variable: Counterproductive_workbehavior

b. Predictors: (Constant), Employee_Larceny, Psychopathy

c. Predictors: (Constant), Employee_Larceny, Psychopathy, Workplace_agression

\section{Coefficients $^{\mathrm{a}}$}


INTERNATIONAL JOURNAL OF ACADEMIC RESEARCH IN BUSINESS AND SOCIAL SCIENCES Vol. 8, No. 7, July 2018, E-ISSN: 2222-6990 @ 2018 HRMARS

\begin{tabular}{llrrrrr}
\hline Model & & \multicolumn{2}{c}{$\begin{array}{c}\text { Unstandardized } \\
\text { Coefficients } \\
\text { Std. Error }\end{array}$} & $\begin{array}{c}\text { Standardized } \\
\text { Coefficients } \\
\text { Beta }\end{array}$ & T & Sig. \\
\hline \multirow{2}{*}{1} & (Constant) & .640 & .157 & & 4.088 & .000 \\
& Psychopathy & .502 & .085 & .532 & 5.932 & .000 \\
& Employee Larceny & .357 & .079 & .404 & 4.502 & .000 \\
& (Constant) & .639 & .162 & & 3.944 & .000 \\
& Psychopathy & .501 & .093 & .531 & 5.370 & .000 \\
& Employee Larceny & .356 & .084 & .403 & 4.252 & .000 \\
& Workplace aggression & .002 & .072 & .003 & .033 & .974 \\
\hline
\end{tabular}

a. Dependent Variable: Counterproductive_workbehavior

\section{Explanation}

To measure independent and dependent variable a linear analysis used. The analysis helps to search out that how independent variables get change in dependent variable. The table shows that $R$ value of independent variable Psy (psychopathy) is .502 and $R$ square 0.200 , $\beta$ value 0.058 , SE value 0.011 , and moderate variable organization commitment which one type is CWB (counterproductive work behavior) is strong regress to independent and dependent variable $R$ value $0.680, R$ square value 0.462 , $\beta$ value 0.813 , SE value 0.087 . Second type of moderate variable WPA (workplace aggression) which is less regress from affective commitment, value of $R 0.653$, $R$ square value 0.426 , ß value 0.527 , SE value 0.062 .

\section{Conclusion}

By using mediator workplace aggression and worker support present study aim analyze relation among psychopathy and counterproductive work behavior. The study was administrated on employee's working in textile sector in Pakistan with positive relation between psychopathy and counterproductive work behavior. Moreover, it is claimed that a workplace aggression mediates the relation between psychopathy and counterproductive work behavior. After examining all information about worker support which play the role, result reveal that it fully mediator workplace aggression and counterproductive work behavior relation. These findings seem to be consistent with the previous studies. The main finding of the study is psychopathy support; it can be used to control the reasoning clarification of workplace events, because support from psychopathy is a personality trait that helps individuals in controlling negative feelings and in facing the challenges of work.

\section{Recommendations}

Organizations should appoint managers that have high anxiety for their employees as success of organization is based on employee's efforts. All the prospects of employees should be fulfilled. When organization shows concern for employee's larceny by treating them well, then employees obviously react in a positive manner. Organizations should discourage aggressive behavior of employees. They should advocate toot gust blowing polices in order to report the unethical behavior of employees. And toot blowers should be encouraged to report confidently. The manager of the organization should encourage for improving ethical environment at workplace aggression.

As manager is the representative of organization, he should be guided to fulfill the organizational obligations properly; this will motivate employees to play their role effectively. One 
INTERNATIONAL JOURNAL OF ACADEMIC RESEARCH IN BUSINESS AND SOCIAL SCIENCES

Vol. 8, No. 7, July 2018, E-ISSN: 2222-6990 @ 2018 HRMARS

of the important findings of current research was the role of psychopathy as a potential variable for reducing workplace aggression. The organization should hire such individuals who have psychologically hardy personalities, because they can perform better than others even in stressful situations. Organizations should introduce such trainings programs which promote the hardihood attitude of the employees which will results in better organizational outcomes.

\section{Future Implications}

The present work aims to overcome and reduce problems faced in past however some limitations still exist that should be focused and remove in coming years. Due to shortage of resources like finance, time then approach to limited staff member related to different departments i.e. exploration, purifying each having different working condition, environment, geographic area, culture all these factors are responsible for transporting changes in answers of some questions. Due to short time period the main limitation that present study faces small sample size that is just 120 so, in future more samples size should be consider before analyzing data. Data was collected from the organizations working in textile sector.

Data collection of this study is done by questionnaire survey, other method of collecting data like group discussion, interview, can provide more strength to the topic if conducted in near future. This study can also be governed by addressing government organization by using variables other than employee aggression and psychopathy in order to analyze the impact of different.

\section{Rub Nawaz}

(Corresponding Author)

MPhil Scholar (Department Public Administration)

Government College University, Faisalabad Pakistan

Email: rub.nawaz10805@gmail.com

\section{References}

Alexander, S., \& Nick, B. (2016),"Understanding counterproductive knowledge behavior: antecedents and consequences of intra-organizational knowledge hiding", Journal of Knowledge Management

Amjad., \& Al-Nasser, M, B. (2015),"Examining the relationship between organizational coaching and workplace counterproductive behaviors in the United Arab Emirates", International Journal of Organizational Analysis

Caroline, A., \& Vincent, R. (2014),"Counterproductive behaviors", Team Performance Management

Chockalingam, V., Satish P, D., \& Claudio, M. (1998),"The effect of corporate social responsibility on employee counterproductive behavior", Cross Cultural Management: An International Journal

Christopher, E, Whelpley., \& Michael, A, M. (2016),"Self-esteem and counterproductive work behaviors: a systematic review", Journal of Managerial Psychology

Dennis, R., \& Self-Terry, B. (2014),"Negligent retention of counterproductive employees", International Journal of Law and Management,

Habib-ur-Rehman,H., Idrees,H., \& Ullah,A. (2017) "Organization and usage of information resources at Deeni Madaris libraries in Pakistan", Library Review, 66 (3) 163-178

Harris., \& Ogbonna. (2014) "The mediating role of psychological needs in the relation between qualitative job insecurity and counterproductive work behavior", Career Development International 
INTERNATIONAL JOURNAL OF ACADEMIC RESEARCH IN BUSINESS AND SOCIAL SCIENCES Vol. 8, No. 7, July 2018, E-ISSN: 2222-6990 @ 2018 HRMARS

Jawaid, S, T., Abbas, S., \& Saleem,S,M. (2017) "Democracy and international financial integration in Pakistan", Indian Growth and Development Review, 10 (1) 16-31

Jonas, D., Joeri, H., \& Filip, D, F. (2016). The effect of state core self-evaluations on task performance, organizational citizenship behavior, and counterproductive work behavior, European Journal of Work and Organizational Psychology

Joseph, A, M., Yoerger, N., \& Lehmann-Willenbrock,, J, J. (2015),"Would you please stop that! The relationship between counterproductive meeting behaviors, employee voice, and trust", Journal of Management Development

Kari, B., Stacey, R, K., \& Paul, E, S., (2014): Bored employees misbehaving: The relationship between boredom and counterproductive work behavior, Work \& Stress

Khan,F. (2016) "Combating corruption in Pakistan", Asian Education and Development Studies, 5 (2)195-210

Lobnikar., \& Pagon, (2014)," Conflict, Bullying, and Counterproductive Work Behavior", the International Journal of Organizational Analysis,

Mahmood, K., Hameed,A _.\& Haider,S,J .(2006) "Libraries in Pakistan: a systemic study", Library Review,55 (1) 20-34,

Mahmood,K. (2005) "Multipurpose community telecenters for rural development in Pakistan", The Electronic Library 23 (2)204-220,

Mahmood, K., Hameed, A .\& Haider,S,J. (2017) "Library fundraising in Pakistan", Library Management, 26 (8/9) 429-438,

Manuela, M., Anja, F., Bruno, S., (2017) "Task variety and counterproductive work behavior", Journal of Managerial Psycholog

Mingzheng, W., Xiaoling, S., Delin, Z., \& Ci, W. (2016) "Moderated mediation model of relationship between perceived organizational justice and counterproductive work behavior", Journal of Chinese Human Resource Management

Misbah, N., \& Ambreen,B. (2012) "Examining workplace deviance in public sector organizations of Pakistan", International Journal of Social Economics 39 (4) 240-253

Raza,S,A., Jawaid,A,T., \& Hassan,A. (2015) "Internet banking and customer satisfaction in Pakistan", Qualitative Research in Financial Markets, 7 (1) 24-36

Rui-Ting, H., Hsi-Sheng, S., Chia-Hua, H., \& Ching-Wen,W. (2017)," Minimizing counterproductive work behaviors: the roles of self-determined motivation and perceived job insecurity in organizational change ", Journal of Organizational Change Management

Satish, P, D., Jacob, J., \& Xiaonan, S. (2005),"The impact of emotional intelligence on counterproductive behavior in China", Management Research News

Suzy, Fox., Paul, E., \& Spector. (2015). "The Many Roles of Control in a Stressor-Emotion Theory of Counterproductive Work Behavior" In Employee Health, Coping and Methodologies.

Ullah, A. (2016) "Differentiation in organizational structures of university libraries in Pakistan", Library Management, 37 (8/9) 507-519

Wenzhi, Z., Yen-Chun, J, W., XiaoChen, C., \& Shu-Jou, L. (2017)," Why do employees have counterproductive work behavior? The role of founder's Machiavellianism and the corporate culture in China ", Management Decision

Yan, Z., \&Long, Ji, (2017)," Leadership styles and employees' voluntary work behaviors in the Ghanaian banking sector ", Leadership \& Organization Development Journal 
INTERNATIONAL JOURNAL OF ACADEMIC RESEARCH IN BUSINESS AND SOCIAL SCIENCES

Vol. 8, No. 7, July 2018, E-ISSN: 2222-6990 @ 2018 HRMARS

Yong, H., Xiaozhi, L., \& Zhaozhong, L. (2010),"In search of excellence: spiritual training program and junior managers' counterproductive work behavior in China", Human Resource Management International Digest 